\title{
Trends in Emission Standards and the Implications for Bus Fleet Management: Technology Assessment for Brisbane Transport
}

\author{
Anish C. Patil and Kerry Brown
}

\begin{abstract}
Cities around the world have set ambitious emissions reduction targets. They are promoting public transport in order to reduce urban pollution from the transportation sector. Cleaner and less polluting city transit buses are paramount if cities are to attain their ambitious emissions reduction targets, as transit buses are high usage vehicles that operate in heavily congested areas where air quality improvements and reductions in public exposure to harmful air contaminants are critical. Decision to invest in a new bus is based on the cost, technology and emission standards. Frequent changes in the emission standards and evolution of bus technology adds to the uncertainty in decision making. A bus has a life expectancy of about 20 years - during its lifespan if the emission standards change and the bus can no longer satisfy the requirements then it has to be phased out or upgraded to comply with the emission requirements - which costs money and time thus leading to financial and service losses. The objective of a decision maker while investing is to optimize the returns of investments - low costs and lower emissions. This paper will look at the Brisbane Transport as a case study - the aim of this paper is to perform comparative technology assessment and based on that provide recommendations to the Brisbane Transport fleet manager during the selection of new buses, in order to attain the 2026 patronage and emissions targets set by Brisbane.
\end{abstract}

\section{INTRODUCTION}

$\mathrm{B}$ RISBANE city council predicts huge population growth in Brisbane, especially in the suburbs. With population growth comes higher traffic, more vehicles, more emissions hence Brisbane City Council in their 'Living in Brisbane 2026 - Vision for Brisbane' and 'Climate Change and Energy Taskforce - A Call for Action' documents have identified safe, reliable and clean public transport as means to keep Brisbane's air clean and reduce greenhouse gas emissions to counteract the impacts of climate change [1]. The primary environmental objective of any city is to reduce human exposure to harmful pollutants and at the same time not hindering the movement of people. This objective can be achieved in two ways - reduce the number of vehicles and reduce the pollution from each vehicle. Number of vehicles can be reduced by improving the public transport and simultaneously encouraging the residents to use public

Manuscript received March 14, 2008

Anish C. Patil is a PhD student at the Faculty of technology, Policy and Management - Delft University of Technology, Netherlands (Corresponding author - phone: +31 152788989; fax: +31 152783422; e-mail: a.patil@tudelft.nl).

Kerry Brown is a Professor at the Faculty of Business, Queensland University of Technology, Australia (e-mail: ka.brown@qut.edu.au). transport instead of driving their personal automobiles. And pollution from each vehicle can be reduced by implementing stringent emissions regulations and promoting the use of alternative fuel vehicles that have lower emissions.

Firstly, this paper will forecast the demand for new public transport buses that will allow Brisbane Transport to achieve the 2026 patronage targets. Secondly, this paper focuses on studying the trends in emission standards during the last two decades and the implications of future emission standards. Thirdly, the paper will perform comparative technology assessment (using techniques such as trend analysis and forecasting) to compare and contrast between different bus technologies, to find out appropriate bus technology for Brisbane Transport buses in order to meet the 2026 emissions targets. Finally the paper will give recommendations to the Brisbane Transport bus fleet manager, with respect to the implications of future emission standard trends and the choice of alternative fuel buses for Brisbane Transport's fleet.

\section{BRISBANE TRANSPORT}

Brisbane Transport is a business unit of Brisbane City Council, operating suburban and urban bus services in the Brisbane metro area. The current Brisbane transport fleet is 887 buses (as of Jan 2008) (http://www.brisbanetransport.info/fleetlist.php). The fleet has a balance of CNG buses (Compressed Natural Gas) and Diesel buses (ratio 45:55). Since 2000 only CNG buses have joined the fleet. In line with the above mentioned 2026 Vision documents, Brisbane Transport has formulated two strategies to achieve the 2026 vision for Brisbane - increase the bus patronage and add cleaner (i.e. lower emissions) buses to the fleet.

This research has formulated the following three research questions to provided recommendations to Brisbane Transport fleet manager in order to attain the 2026 patronage and emission targets.

- How many new Buses will Brisbane Transport need?

- The trend over the past 2 decades shows that emission standards are becoming gradually stricter; an important question is whether this trend will continue to become stricter or stabilize in the future?

- Which the type of buses should Brisbane Transport invest in? 


\section{ForeCASTING THE NUMBER OF BUSES NEEDED}

\section{Mathematical Modeling}

\section{Nomenclature}

$\mathrm{P}=$ Patronage $\mathrm{Pb}=$ Patronage per bus

$\mathrm{X}=$ Number of buses in the fleet.

$\mathrm{Y}=\mathrm{Year}$

$\mathrm{Xy}=$ Number of Buses in the fleet in the particular Year, $\mathrm{y}$.

$\mathrm{N}=$ variable $=$ Number of new buses added per year

Note:

1) Average number of buses added per year over the last 10 years is $48.3=48$.

2) Average life-span of the Brisbane Transport bus is about 20 years [2]

Hence, equation 1 that calculates the yearly patronage can be expressed as

$\mathrm{P}=\mathrm{X} \times \mathrm{P}_{\mathrm{b}}$

Equation 1 signifies that to increase the patronage either the number of buses needs to increase or the patronage per bus needs to improve.

Furthermore, for a particular year y, the total fleet can be calculated as shown in equation 2 .

$\mathrm{X}_{\mathrm{y}}=\mathrm{X}_{\mathrm{y}-1}-\mathrm{X}_{\mathrm{y}-20}+\mathrm{N}$

Equation 2 signifies that the total fleet for a year y, can be calculated by adding the number of buses joining the fleet that year to the number of buses in the fleet the previous year and subtracting the number of buses in the fleet 20 years back, as the life span of a bus is about 20 years.

This paper suggests two strategies to achieve the 2026 target of 110 million passengers per year: Increase the amount of buses or increase the patronage per bus,

Strategy 1: Maintain the current average of adding 48 bus per year (average for past 10 years) while increasing patronage per bus $(\mathrm{Pb})$ from 0.08 to 0.1 millions.

Strategy 2: Increase the average buses joining the fleet per year from 48 to 67 buses per year, while keeping the patronage per bus $(\mathrm{Pb})$ at 0.08 millions. The results are shown in Table I.

TABLE I

STRATEGIES TO ACHIEVE PATRONAGE TARGETS

\begin{tabular}{|c|c|c|c|c|}
\hline & \multicolumn{2}{|l|}{$\begin{array}{l}\text { Strategy 1: Add 48 } \\
\text { buses per year. Increase } \\
\text { Pb to 0.1 mil }\end{array}$} & \multicolumn{2}{|l|}{$\begin{array}{l}\text { Strategy 2: Add 67 } \\
\text { buses per year. } \\
\text { Maintain Pb at 0.08 mil }\end{array}$} \\
\hline $\begin{array}{c}\text { Yea } \\
\text { r }\end{array}$ & $\begin{array}{c}\text { Fleet } \\
\text { Strength }\end{array}$ & $\begin{array}{c}\text { Patronage } \\
\text { (millions) }\end{array}$ & $\begin{array}{c}\text { Fleet } \\
\text { Strength }\end{array}$ & $\begin{array}{c}\text { Patronage } \\
\text { (millions) }\end{array}$ \\
\hline 2008 & 817 & 89.87 & 836 & 66.88 \\
\hline 2014 & 867 & 95.37 & 1000 & 80 \\
\hline 2018 & 991 & 109.01 & 1200 & 96 \\
\hline 2022 & 1072 & 117.92 & 1357 & 108.56 \\
\hline 2026 & $\mathbf{1 0 0 5}$ & $\mathbf{1 1 0}$ & $\mathbf{1 3 6 7}$ & $\mathbf{1 1 0}$ \\
\hline
\end{tabular}

This research projects that a fleet strength of 1005 to 1367 buses (Table I) will allow Brisbane Transport to achieve the patronage targets of 110 millions in 2026. Fleet strength of 1005 buses can be achieved by adding 900 new buses, and of 1367 buses can be achieved by adding 1262 new buses over the next 20 years - for detailed analysis please refer to [3]. This figure is much lower than the fleet target of 1785 suggested by Translink and the Brisbane Council [4]. After reading the Brisbane Transport plan [4] it is evident that Brisbane Transport is aiming at increasing fleet size to increase patronage. But in fact Brisbane Transport should simultaneously aim at increasing the patronage per bus. Further comparative analysis of comparable global cities will clarify the above statement. For detailed analysis please refer to [3].

Fig. 1 shows patronage per bus in comparable global cities: Sydney, Australia (Includes Sydney and New Castle) [5]; Perth, Australia [6]; Singapore [7], [8]; Hong Kong, China [9]; Atlanta, USA [10]; New York, USA [11]. As seen in Fig. 1, Brisbane has one of the lowest (0.08 million) patronage per bus compared to other cities. Singapore and Hong Kong are much higher. Even the patronage per bus for Sydney (another Australian city) is higher than Brisbane by almost 20\%. Buses in American cities (cities that have demographics and economy similar to Brisbane) such as Atlanta and New York also have $20-25 \%$ higher patronage per bus than Brisbane.

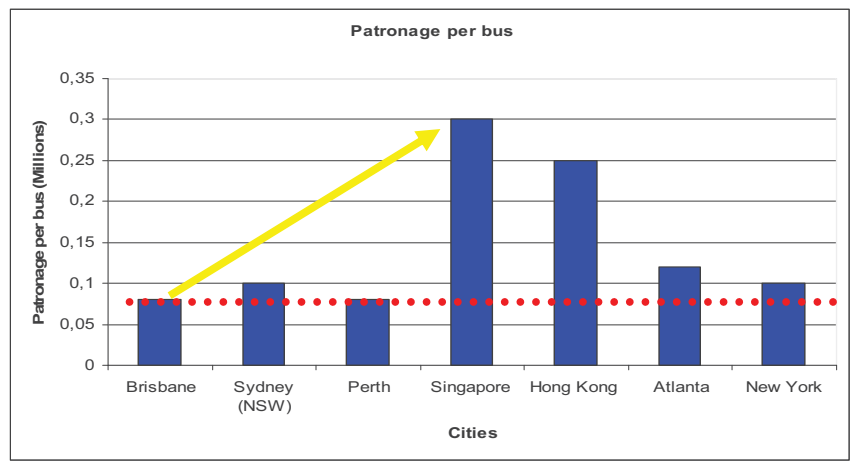

Fig. 1. Patronage per bus - overview of comparable cities

Brisbane Transport will need between 900 and 1262 buses (depending on the patronage per bus) over the next 20 years to meet its patronage targets. For the purpose of this analysis we round the figure to 1000 new buses. About 1000 new buses will require huge investments - more than 600,000 Australian dollars per bus and millions of dollars per depot [12]. Therefore, the bus fleet manager is faced with a number of challenges concerning the selection of these 1000 buses. The new buses should have to be reliable, efficient, and environmentally friendly and at the same time be cost effective in terms of purchasing price, operation and maintenance in order to optimize the tax payer's resources.

Decision making for procurement of new buses is heavily based on the emission standards as every new bus should comply with the emission standards [13], [14]. In case a new bus satisfies the 'current most stringent emission standards' then that bus is often selected [2]. What makes the job of the 
decision maker difficult is the uncertainty regarding future emission standards. Any decision today could have repercussions for the next 25 years or so as the life cycle of a regular bus constitutes 20 years in addition to a lag time of about 4 to 5 years for the process of order and delivery. The next part of the paper will analyze the emission standard trends and its implications for fleet management, in terms of technological assessment of different buses and compatibility to the existing fleet of Brisbane Transport.

\section{TRENDS IN EMISSION STANDARDS}

Currently, emissions from only the diesel buses are limited by corresponding emission standards - alterative fuel buses such as CNG, Hybrid or Fuel cell buses do not have emission standards - they comply with the corresponding diesel emission standards. Emission standards are minimum compliance requirements that set the limits to the amount of pollutants a vehicle can emit into the air. Emission standards for the heavy duty diesel vehicles generally limit exhaust emissions of four pollutants [15], [16]

- Particulate matter (PM) - soot

- Nitrogen oxides (NOx) - lung irritant and smog.

- Carbon monoxide (CO) - poisonous gas

- Hydrocarbons (HC) - smog

PM is the general term for the mixture of solid particles and liquid droplets found in the air. Particulate matter includes dust, dirt, soot, smoke and liquid droplets. NOx emissions produce a wide variety of health and welfare effects. NOx emissions are an important precursor to acid rain that may affect both terrestrial and aquatic ecosystems. $\mathrm{CO}$ is the product of the incomplete combustion of carbon-containing compounds [17]. CO contributes to greenhouse gas effect and global warming. HC is comprised of unburned hydrocarbons in the fuel; it contributes to smog (blue haze over heavily populated cities). Carbon dioxide emissions correlate to the fuel efficiency of the vehicle, and generally are not limited within the emission standards. For example, the current European emission standards do not set limits for carbon dioxide emissions - carbon dioxide is controlled through voluntary agreement between the European Union (EU) and automobile manufacturers.

Australian vehicle emissions standards have always been based on overseas standards. Globalization of the motor vehicle industry and the small size of the vehicle market in Australia do not call for the development of unique Australian standards. Australia regulates its vehicle emissions through Australian Design Rules (ADRs). The ADRs set the standards that new vehicles need to comply with prior to their first supply to the Australian market [18]. The Australian Government has adopted European standards as this approach provides the desired environmental outcome and facilitates international trade in motor vehicles [19]. Therefore, European standards are analyzed in this case study.

European emission standards are sets of requirements outlining the limits for tailpipe exhaust emissions for the new vehicles sold in EU member states. The emission standards are defined in a series of European Union directives emission standards for new heavy-duty diesel engines are commonly referred to as Euro I ...V. A proposal for the Euro VI emission standards is in the planning, which may probably be introduced after 2011 in Europe. Euro V will be introduced later this year. The introduction date signifies that all new vehicles sold after that date should comply with the Euro V. Usually there is a grace period of 3 to 4 years for older vehicles to comply with the regulations. During this time the older vehicles can be phased out or updated with new technologies to comply with the new standard. Euro V differs from Euro IV in its stricter emission requirement for NOx. $\mathrm{PM}, \mathrm{HC}$ and $\mathrm{CO}$ limits are expected to be similar to Euro IV. Euro VI is a standard in planning. It is proposed to be introduced in the European Union after 2011. Given that Euro $\mathrm{V}$ will be introduced later this year in Europe; an implementation date of 2011 (not finalized yet) for Australia is currently considered [18], [19]. Hence Australian public transport managers can enjoy a 3 to 4 years grace period and learn from their European counterparts about their experiences of complying with Euro V and Euro VI.

Fig. 2 below, presents the trends in emission standards. The permissible NOx emission limits have reduced by $75 \%$, PM limits have reduced by over $97 \%$, HC limits have reduced by $58 \%$ and $\mathrm{CO}$ limits have reduced by $67 \%$. It is expected that clean diesel buses equipped with particulate filters can substantially reduce particulate emissions when they are used with low sulfur diesel fuel. NOx and PM retrofitting coupled with low sulfur diesel will enable diesel buses to comply with Euro V standards upon its introduction [20]-[22].

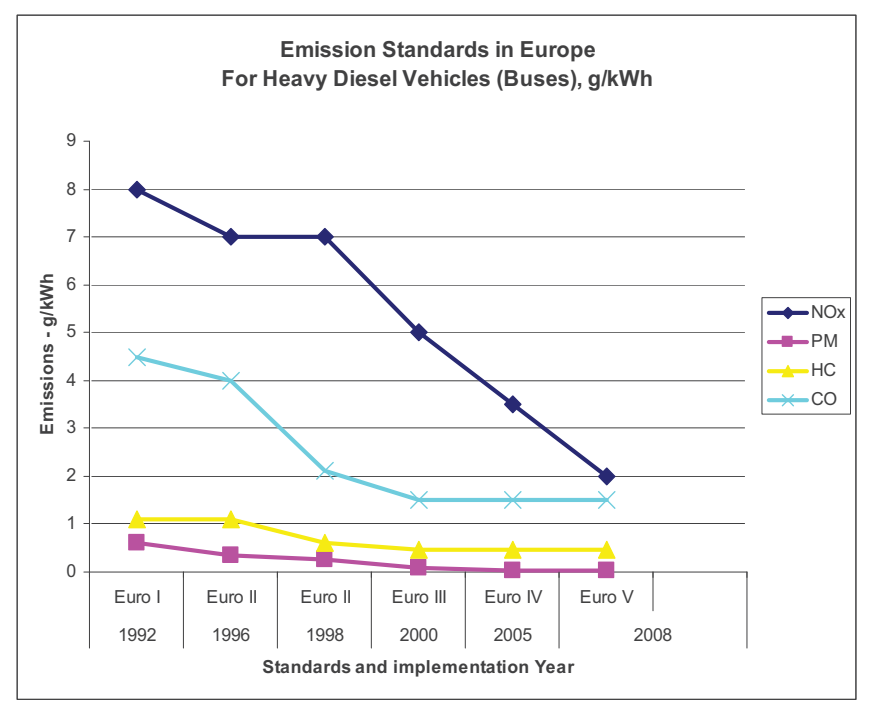

Fig. 2. Trends in Emission standards 
TABLE II

TECHNOLOGY ASSESSMENT FOR PUBLIC TRANSPORT BUSES [23]-[25]

\begin{tabular}{|c|c|c|c|c|c|}
\hline Criteria & Clean Diesel & CNG & Hythane & Hybrid & \begin{tabular}{|l|} 
Hydrogen/ \\
Fuel Cell \\
\end{tabular} \\
\hline \begin{tabular}{|l} 
Purchase \\
Price (AUD)
\end{tabular} & @600,000 & @700,000 & @700,000 & @1,300,000 & $@ 2,000,000$ \\
\hline Fuel & $\begin{array}{l}\text { Fuel is easily } \\
\text { available }\end{array}$ & $\begin{array}{l}\text { Use the existing } \\
\text { Fuel infrastructure }\end{array}$ & $\begin{array}{l}\text { Use the existing } \\
\text { CNG infra }\end{array}$ & $\begin{array}{l}\text { Can use existing } \\
\text { fuel infrastructure }\end{array}$ & $\begin{array}{l}\text { Lack of fuel and } \\
\text { fueling infra }\end{array}$ \\
\hline Emissions & $\begin{array}{l}\text { Higher } \\
\text { emissions }\end{array}$ & $\begin{array}{l}\text { Reduced emissions } \\
\text { compared to diesel }\end{array}$ & $\begin{array}{l}\text { Reduced emissions } \\
\text { compared to CNG }\end{array}$ & Lower emissions & $\begin{array}{l}\text { No tailpipe } \\
\text { emissions }\end{array}$ \\
\hline Technology & $\begin{array}{l}\text { Mature } \\
\text { technology }\end{array}$ & $\begin{array}{l}\text { Old technology with } \\
\text { new application }\end{array}$ & $\begin{array}{l}\text { Minor modifications } \\
\text { to CNG technology }\end{array}$ & $\begin{array}{l}\text { New technology - } \\
\text { unproven service } \\
\text { record }\end{array}$ & $\begin{array}{l}\text { Technological } \\
\text { barriers still to be } \\
\text { overcome. }\end{array}$ \\
\hline Safety & Most stable fuel & $\begin{array}{l}\text { NG is stored in high } \\
\text { pressure cylinders - } \\
\text { high potential for } \\
\text { leaks, explosion. }\end{array}$ & $\begin{array}{l}\text { NG and } \mathrm{H} 2 \text { stored at } \\
\text { high pressure - } \\
\text { potential for leaks } \\
\text { and explosion }\end{array}$ & $\begin{array}{l}\text { Diesel is a stable } \\
\text { fuel, but the electric } \\
\text { motor drive system } \\
\text { presents potential } \\
\text { for electrocution }\end{array}$ & $\begin{array}{l}\text { Hydrogen is stored } \\
\text { in high pressure } \\
\text { cylinders - high } \\
\text { potential for leaks } \\
\text { and explosion. }\end{array}$ \\
\hline Performance & $\begin{array}{l}\text { Proven service } \\
\text { record }\end{array}$ & $\begin{array}{l}\text { Limited range of } \\
\text { operation }\end{array}$ & $\begin{array}{l}\text { Limited range of } \\
\text { operation as }\end{array}$ & $\begin{array}{l}\text { Flexibility due to } \\
\text { dual power system. }\end{array}$ & $\begin{array}{l}\text { Unproven } \\
\text { technology and } \\
\text { unknown durability }\end{array}$ \\
\hline \begin{tabular}{|l|} 
Summary \\
\end{tabular} & $\begin{array}{l}\text { Stable fuel, } \\
\text { proven } \\
\text { technology but } \\
\text { higher emissions }\end{array}$ & $\begin{array}{l}\text { Low emissions and } \\
\text { proven technology. } \\
\text { Bit expensive than } \\
\text { diesel }\end{array}$ & $\begin{array}{l}\text { Very low emissions } \\
\text { - combines } \\
\text { strengths of NG and } \\
\text { H2 }\end{array}$ & $\begin{array}{l}\text { Low emissions, but } \\
\text { new technology and } \\
\text { expensive }\end{array}$ & $\begin{array}{l}\text { Lowest on road } \\
\text { emissions but } \\
\text { unproven tech and } \\
\text { very expensive }\end{array}$ \\
\hline
\end{tabular}

\section{TECHNOLOGY ASSESSMENT}

\section{Mathematical Modeling}

Compared to diesel bus a CNG bus will emit 40\% less NOx, emit $0 \%$ less PM, emit 15\% less GHG and cost $15 \%$ more [24], [26], [27].

Compared to diesel bus a Hythane buses will emit 55\% less NOx, emit almost the same PM, emit 20\% less GHG and cost $15 \%$ more [27]-[30].

Compared to diesel bus a Hybrid buses will emit 75\% less NOx, emit 60\% less PM, emit 20\% less GHG and cost $100 \%$ more [23], [24].

Compared to diesel bus a Fuell Cell buses will emit 100\% less NOx, emit 100\% less PM, emit 100\% less GHG and cost $200 \%$ more [24], [31].

\section{Nomenclature}

$\mathrm{X}=$ number of buses in the fleet

$\alpha=$ co-efficient for NOx emissions

$\beta=$ co-efficient for PM emissions

$\varphi=$ co-efficient for GHG emissions

$\lambda=$ co-efficient for Price of a bus

Let $d$ represent diesel buses, $c$ the CNG buses, $t$ the Hythane buses, $b$ the Hybrid buses and $f$ the Fuel Cell buses

$\mathrm{i}=\{d, c, t, b, f\}$
Assuming, each Diesel Bus emits 1 unit of NOx, 1 unit of PM and 1 unit of GHG and cost 1 unit of Price. As the fleet is composed of different buses, the co-efficient for different types of buses can be quantified (based on the above emissions data) as shown in Table III.

\section{TABLE III}

C0-EFFICIENT FOR CNG, HYTHANE, HYBRID AND FUEL-CELL BUSES

\begin{tabular}{|l|l|l|l|l|}
\hline $\begin{array}{l}\text { Type of } \\
\text { Buses }\end{array}$ & $\begin{array}{l}\text { Co-efficien } \\
\mathbf{t} \text { for NOx }\end{array}$ & $\begin{array}{l}\text { Co-efficien } \\
\text { for PM }\end{array}$ & $\begin{array}{l}\text { Co-efficien } \\
\mathbf{t} \text { for GHG }\end{array}$ & $\begin{array}{l}\text { Co-eff for } \\
\text { Price }\end{array}$ \\
\hline Diesel & $\alpha_{d}=1$ & $\beta_{d}=1$ & $\phi_{d}=1$ & $\lambda_{d}=1.0$ \\
\hline CNG & $\alpha_{c}=0.6$ & $\beta_{c}=1$ & $\phi_{c}=0.85$ & $\lambda_{c}=1.15$ \\
\hline $\begin{array}{l}\text { Hythan } \\
\text { e }\end{array}$ & $\alpha_{t}=0.45$ & $\beta_{t}=1$ & $\phi_{t}=0.8$ & $\lambda_{t}=1.15$ \\
\hline Hybrid & $\alpha_{b}=0.25$ & $\beta_{b}=0.4$ & $\phi_{b}=0.8$ & $\lambda_{b}=2.0$ \\
\hline $\begin{array}{l}\text { Fuel } \\
\text { Cell }\end{array}$ & $\alpha_{f}=0$ & $\beta_{f}=0$ & $\phi_{f}=0$ & $\lambda_{f}=3.0$ \\
\hline
\end{tabular}

Note: (1) The above coefficient's for NOx, PM and GHG and Price are based on the existing technologies. To compensate for innovations in the future bus technologies, the model reduces the total projected emissions by $1 \%$ per year starting from 2010 until 2026.

(2) 1000 new buses will be added until 2026.

(3) All calculations are done for tailpipe emissions not 'well-to-wheel' emissions

Emissions from 1 bus $=\alpha N O x+\beta P M+\phi G H G$ 
Total fleet emissions is the sum of the total NOx, PM and GHG emissions from all the buses in the fleet. Hence, emissions from the entire fleet for a particular year, $y$

$=\sum_{x=1}^{X} \alpha_{i} N O x+\sum_{x=1}^{X} \beta_{i} P M+\sum_{x=1}^{X} \phi_{i} G H G$

Costs for procuring 1000 new buses until 2026

$=\sum_{x=1}^{X} \lambda_{i}$ Price

Fig. 3 below shows the comparative technology assessment performed for the selection of the 1000 new buses. Adding CNG buses until 2026, allows Brisbane Transport to considerably lower (compared to when only Diesel buses are added until 2026) NOx emissions for the total fleet in 2026 - this NOx reduction comes at marginally higher price compared to Diesel buses. But, Hythane buses deliver greater reduction in NOx and GHG compared to $\mathrm{CNG}$ buses with equivalent costs as CNG buses. Hythane buses and Hybrid buses have similar potential in reducing NOx and GHG emissions, but Hybrid buses are much better for PM reduction. Of course, hydrogen buses have a greater potential to reduce all NOx, PM and GHG emissions, but this comes at a considerably higher costs (threefold than the Diesel bus option).

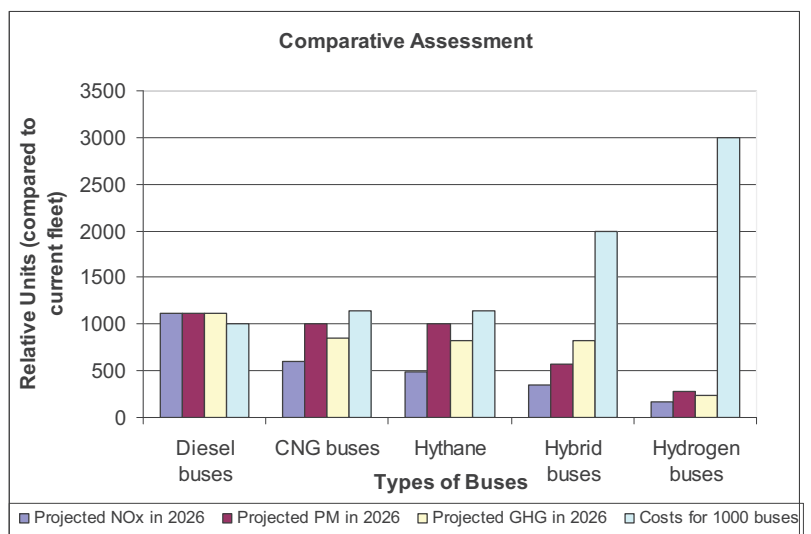

Fig. 3. Comparative assessment of different bus technologies w.r.t to emissions and costs.

\section{DISCUSSION}

Emission limits for PM and NOx are already quite stringent and further tightening is unlikely [22]. From 1992-2008 NOx emission limits have reduced by $87 \%$ and PM limits have reduced by over $97 \%$ and further tightening won't bring substantial environmental and health benefits. Until recently, $\mathrm{CO} 2$ was not regulated but controlled by voluntary targets between EU and bus manufacturers. As shown in the previous analysis this has not helped to reduce CO2. Hence, the future emission standard, Euro VI that is expected to be implemented in 2013-2014 in Australia, may focus on regulating $\mathrm{CO} 2$ emissions. As shown in Fig. 5 below, California (throughout USA from 2010) will introduce new standards from 2007 reducing NOx limits to $0.27 \mathrm{~g} / \mathrm{kW} . \mathrm{hr}$ and PM limits to $0.013 \mathrm{~g} / \mathrm{kW} . \mathrm{hr}$ [16]. Fig. 5, gives the idea of where Euro VI might aim at.

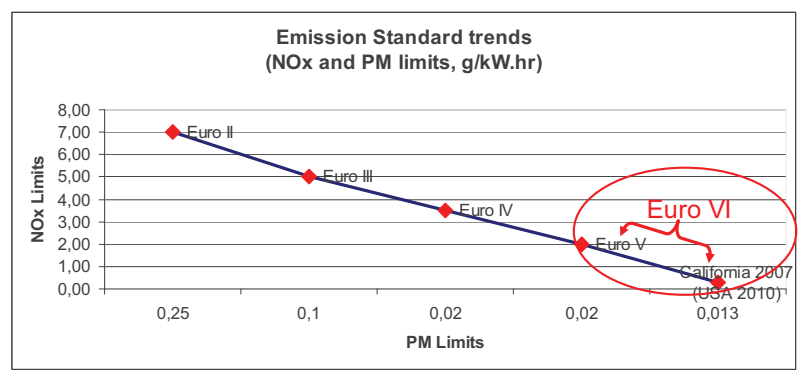

Fig. 5. Euro VI - How low can it go?

There is some uncertainty about Euro VI. Although further tightening of PM and NOx limits would not give substantial benefits, but Europe may like to follow Californian and US EPA standards and reduce NOx and PM limits further. Australia adheres to Euro standards but will not introduce Euro V until at least 2010 and Euro VI until after 3-4 years later than Europe [19]. If Europe introduces Euro VI in 2010, Australia may introduce it in 2013 or 2014. Hence Australian public transport managers can gain from experiences of their European counterparts about new technologies to comply with emissions standards.

CNG buses are inherently clean, and are themselves capable of reducing emissions, but keeping in view the future stringent emission standards - Brisbane Trasnport should invest in Hythane buses, as seen from Fig. 3, Hythane buses will allow Brisbane Transport to considerably lower NOx and GHG emissions and that too at only a marginally higher cost. Hythane buses are better equipped to satisfy future stringent emission standards. The existing CNG bus can be easily converted to Hythane bus with minor modifications. Natural gas regulators and carburetors are converted with only minor modification such as change of spring to accommodate the lighter gas [32]. Hythane, a patented product, is a mixture of $20 \%$ by volume of Hydrogen and $80 \%$ Methane [33]. China plans to replace 10,000 diesel buses with low emission Hythane powered buses for five major cities before the Olympic Games in 2008 [34]. Many other cities globally are experimenting with Hythane. Further, Hythane buses can comply with Euro V and Euro VI standards. Current hybrid and fuel cell bus technology is still immature and thus currently has high investment costs for these buses. Although hybrid buses have higher fuel efficiency, the technology is undeveloped with high maintenance and repair costs that do not warrant the investment in such expensive technology. Fuel cell and hydrogen buses are in their infancy and experimental phase - hence huge investments in this technology should be avoided at this time unless subsidized by the Australian or Queensland government.

\section{RECOMMENDATION}

The decision making process outlined in this research indicates that Brisbane Transport should only invest in the Hythane buses for the future - they need about 1000 new buses over the next 20 years. Also, Hythane buses can use the existing CNG infrastructure with minor modifications. Brisbane Transport would be well positioned to convert older 
CNG bus fleet into Hythane with the introduction of stricter emission standards, as Hythane buses are better poised to deal with the uncertainties in future emission standards. Although, decision making for the procurement of new buses is an important issue for transit authorities in order to attain the future environmental targets - not much research has been done so far to assist the fleet manager to make these procurement decisions. This research aims to bridge this gap in literature. The decision-making process outlined in this research; based on forecasting, trend analysis and technology assessment; is adaptable to other types of infrastructure decisions to enable strategic procurement. The authors understand that there is a big scope for improvement in terms of future research as this research done for the Brisbane Transport case study is by no means comprehensive as it ignores many other sources of uncertainties and limitations faced by a decision maker during procurement. Future research should be more comprehensive and could build on the decision making process discussed in this paper to come up with a decision making tool for the benefit of transit authorities.

\section{ACKNOWLEDGEMENT}

The authors would like to thank CIEAM (Co-operative Research Center for Engineering Asset Management), Australia for facilitating this research.

\section{REFERENCES}

1. Brisbane-Council, Our shared vision - Living in Brisbane 2026. 2006, Brisbane City Council.

2. M. Welsh, Importance of Emission Standards during the Procurement of new Buses, A. Patil, Editor. 2007: Brisbane.

3. A. Patil, and K. Brown. Scenario Analysis to Assist Brisbane Transport in Achieving 2026 Patronage and Clean-Air Targets in Twelfth Annual Conference of the International Research Society for Public Management. 2008. Brisbane.

4. Brisbane-Council, Transport Plan for Brisbane 2006 - 2026 (Draft). 2007, Brisbane City Council: Brisbane.

5. STA-NSW, State Transit Authority of NSW. 2007, State Transit Authority of NSW: Sydney.

6. Transperth. [cited 2008 February 12]; Available from: http://www.transperth.wa.gov.au/AboutUs/AboutTransperth/tabid/276 Default.aspx.

7. SBSTransit. [cited 2008 February 12]; Available from: http://www.sbstransit.com.sg/about/operational.aspx.

8. SBSTransit, 2006 Annual Report. 2006, SBSTransit Ltd: Singapore.

9. KMB. KowLoon Motor Bus. [cited 2008 February 12]; Available from: http://www.kmb.hk/english.php?page=profile\&file=kingdom/index.ht $\underline{\mathrm{ml}}$.

10. MARTA, 2006 Annual Report. 2006, Metropolitan Atlanta Rapid Transit Authority: Atlanta.

11. MTA. MTA Bus Company. [cited 2008 February 12]; Available from: http://www.mta.info/busco/about.htm.

12. C.J. Cockroft, and A.D. Owen. A Cost Benefit Analysis of Perth's Hydrogen Fuel Cell Buses. in British Institute of Energy Economics (BIEE) 2005. Oxford, UK.

13. J. Hao, J. Hu, and L. Fu, Controlling vehicular emissions in Beijing during the last decade. Transportation Research Part A: Policy and Practice, 2006. 40(8): p. 639-651.

14. AATA, Alternative Fuels, Emissions, \& Technology, in White Paper. 2002, Ann Arbor Transportation Authority: Ann Arbor.

15. M.P. Walsh, Vehicle Emission Trends. 2000, European Conference of Ministers of Transport: Paris.
16. DieselNet. Emission Standards. http://www.dieselnet.com/standards/.

17. J.T. Cohen, Diesel vs. compressed natural gas for school buses: a cost-effectiveness evaluation of alternative fuels. Energy Policy, 2005. 33(13): p. 1709-1722.

18. DOTARS. Australia Design Rules - Vehicles and the Environment. [cited; Available from: www.dotars.gov.au/roads/motor/design/adr_online.aspx.

19. DOTARS, Regulation Impact Statement for Vehicle Emissions and Fuel Quality Standards for the Post 2006 Period. 2004, Department of Transport and Regional Services on behalf of Land Transport Environment Committee

20. ARB, Proposed regulation for a public transport bus fleet rule and emission standards for new urban buses. 1999, California Environmental Protection Agency.

21. T\&E, Waiting for Euro 5 and Euro 6 - New Emission Standards for Passenger Cars, Vans and Lorries. 2004, European Federation for Transport and Environment: Brussels.

22. Umweltbundesamt, Future Diesel - Exhaust has legislation for passenger cars, light duty vehicles, and heavy duty vehicles, S. Rodt, Editor. 2003, Federal Environmental Agency (Umweltbundesamt): Berlin.

23. N.N. Clark, et al., Transit Bus Life Cycle Cost and Year 2007 Emissions Estimation. 2007, U.S. Department Of Transportation Federal Transit Administration: Washington

24. WSU, New Engine Technologies, in Diesel emissions reports. 2004, Washington State University - Energy Program: Olympia, Washington.

25. CleanAirNet Advanced Diesel Bus. Clean Air Initiative Volume,

26. CleanAirNet. CNG Bus. [cited 2008 February 12]; Available from: http://www.cleanairnet.org/infopool/1411/propertyvalue-17731.html.

27. I. Alliat, ALT-HY-TUDE Project: The 2 First Hydrogen/Hythane ${ }^{\circledR}$ Refuelling Stations in France. in 23rd World Gas Conference. 2006. Amsterdam

28. R.W. Marmaro, (2006) Hythane -- Bringing Hydrogen to Zero Emissions Reality. Volume,

29. B. Ridell, Malmo Hydrogen and CNG/Hydrogen filling station and Hythane bus project. in Risoe Energy Conference. 2005. Roskilde, Denmark.

30. HydroThane, Clean Technology for Public Transport (CTPT) Hydrogen as a renewable alternative for diesel and gasoline. 2004, Hydrothane.

31. G.-H. Tzeng, C.-W. Lin, and S. Opricovic, Multi-criteria analysis of alternative-fuel buses for public transportation. Energy Policy, 2005. 33(11): p. 1373-1383.

32. B. Nagalingam, F. Duebel, and K. Schmillen, Performance study using natural gas, hydrogen-supplemented natural gas and hydrogen in AVL research engine. International Journal of Hydrogen Energy, 1983. 8(9): p. $715-720$.

33. Hythane. Hythane - Blue Sky, Clean Air. 2007 [cited; Available from: http://www.hythane.com/.

34. R.E. Access, Beijing Invests in Hydrogen, Natural Gas Bus Fleet. 2004 [cited; Available from: www.renewableenergyaccess.com/rea/news/story?id=17355. 